\title{
Effects of green tea catechins on spatial learning abilities of wistar rats
}

\author{
Ambili Gopi Nair' ${ }^{1}$, Shilpa AV ${ }^{2, *}$, Biju Bahuleyan ${ }^{3}, K_{\text {Rajankutty }}^{4}$ \\ ${ }^{1}$ MSc Graduate, Vimala College, Thrissur, Kerala, ${ }^{2}$ Assistant Professor, ${ }^{3}$ Professor and HOD, Dept. of Physiology, ${ }^{4}$ HOD, Small \\ Animal Research Facility, Jubilee Mission Medical College and Research Institute, Thrissur, Kerala, India \\ *Corresponding Author: \\ Email: drshilpamanoj@gmail.com
}

\begin{abstract}
Introduction: Green tea has drawn much attention because of the increase in the number of studies describing its potential health benefits which are attributed to Epigallocatechin-3-gallate (EGCG). Recent studies have also shown that in addition to antioxidant effects, green tea catechins modulates cell cycle signaling, generates non amylodogenic APP, enhances activity in dorsolateral prefrontal cortex etc.

Materials and Method: The study was done in 18 male albino Wistar rats and divided in three groups of six. The spatial learning ability of rats were assessed by their behavior in 8 arm radial maze.

Results: Statistical analysis was done using SPSS version 22 and data analyzed using Independence sample T test, Paired T test and ANOVA. The maze study showed an improvement in spatial learning ability of rats after green tea consumption in group1 and 2 as the time taken by the animal to complete the maze was found to be decreased.

Conclusion: Administration of green tea catechins improves the spatial learning abilities of rats with an improved performance in radial maze tasks. The neuroprotective effect of green tea catechins may be due to their antioxidant property and hence can be used an effective tool in delaying cognitive impairment in elderly.
\end{abstract}

Keywords: Green tea, EGCG, Radial maze, Cognition.

\section{Introduction}

Tea is the most common beverage worldwide, which is consumed as black, green or oolong tea. Among these, green tea has significant effects on human health. Green tea is obtained from Camellia sinensis which is an evergreen shrub or small perennial tree. ${ }^{1}$ The chemical composition of green tea is complex with proteins, carbohydrates, minerals and trace elements. It also contains trace amounts of lipids, sterols, vitamins (B, C, and E), xanthic bases, pigments and volatile compounds. Fresh leaves contain, 3-4\% of alkaloids known as methylxanthines, such as caffeine, theobromine, and theophylline. ${ }^{2}$

Processing of green tea is different from that of black and oolong tea. The freshly harvested leaves are steamed to prevent fermentation which yields a stable dry product. $^{3}$ This steaming process destroys the enzymes but the natural polyphenols are preserved. ${ }^{4}$ The Flavanols in tea are commonly called as Catechins. Fresh tea leaf is unusually rich in the flavanol group which may constitute up to $30 \%$ of the dry leaf weight. There are four kinds of catechins present in green tea: Epicatechin, Epigallocatechin, Epicatechin-3-gallate, and Epigallocatechin-3-gallate (EGCG), with EGCG being the highest in concentration. ${ }^{5}$

In recent years, green tea has drawn much attention because of the increase in the number of studies describing its potential health benefits such as the neuroprotective, anti-inflammatory, antiarthritic, and antibacterial, antiangiogenic, antioxidative and antiviral. $^{6-12}$ The cholesterol-lowering effects of green tea and isolated green tea constituents are under investigation. ${ }^{13}$ These beneficial effects of green tea are attributed to Epigallocatechin-3-gallate (EGCG). Green tea consumption has also been linked to the prevention of many types of cancer. Studies have suggested that GTPs might protect against Parkinson's and Alzheimer's diseases and other neurodegenerative diseases. ${ }^{6}$

Recently several studies have shown that in addition to antioxidant effects, green tea catechins modulates cell cycle signaling, generates nonamylodogenic APP, enhanced activity in dorsolateral prefrontal cortex etc. ${ }^{14-16}$ The present study is focused to know the dose related effects of water containing green tea catechins on spatial learning ability in rats.

\section{Materials and method}

The experiment was conducted in the Small Animal Research Facility at Jubilee Mission Medical College and Research Institute, Thrissur. Before starting the experiment institutional animal ethics committee (IAEC) approval was obtained. The study was done by taking a sample of 18 male albino Wistar rats.

\section{Preparation of Green tea}

Green tea extracts, GTE (ZENITH NUTRICORP, 16C Reading Road, Edison, NJ, and O8817 USA) was purchased online. Green tea was prepared by adding extracts to warm water and then cooled to room temperature. The extracts were prepared in two concentrations: $0.5 \%$ (125 mg GTE in $25 \mathrm{ml}$ water) and $1 \%$ (250 mg GTE in $25 \mathrm{ml}$ water). It was then poured into the animals feeding bottles. The rats were supplied with freshly prepared tea every morning. 


\section{Animals and Experimental Design}

Male Albino Wistar rats (Rattus norvegicus) obtained from Small House Mannuthy, 8-10 months age and weighing between 200-350 g were used for the study. They were kept in the Small Animal Research Facility at Jubilee Mission Medical College and Research Institute, Thrissur. The animals were housed in wire mesh cages and allowed to adjust to the new environment for one week before starting the experiment. They were kept under standard conditions of light and temperature.

Animals were randomly divided into two experimental groups and a control group with six animals in each group, as follows:

Group 1: Animals were given standard diet and 0.5\% concentration of green tea.

Group 2: Animals were given standard diet and $1 \%$ concentration of green tea.

Control: Animals were given standard diet and tap water.

Parameters assessed:

a. Radial maze-learning ability: Both 1 and 2 weeks after starting the green tea catechins administration, the rats learning ability was tested by an assessment of their behavior in an 8-arm radial maze. Before starting the experiments the entire animals were trained. A time period of 10 minutes was set as standard time for them to cover all the 8 arms of the maze. Small amount of feed was kept at all the 8 ends of the maze. The animal was kept in the center of the maze and allowed to run freely through the arms. The time taken by an animal to cover all the arms was noted. Each animal was given 2 trials after overnight fasting. From this working memory was assessed. Repeated entry into the same arm was considered as error in working memory and poor learning skills.

\section{Results}

Statistical analysis was done using SPSS version 22. The data was represented as mean and standard deviation and analysis was done using Independence sample T test, Paired T test and ANOVA. P value < 0.05 was taken as significant.

The maze study showed an improvement in spatial learning ability of rats after green tea consumption in Group 1 and 2. The time taken by an animal to cover all the 8 arms of radial maze was found to be decreased after taking green tea (Table 1.1). In Group 1 there are no significant changes as $\mathrm{P}$ value $>0.05$ but there is significance in Group 2 as $\mathrm{P}$ value $<0.05$.

\section{Maze Study}

Table 1: Group1 \& Group 2: Before and after green tea intake

\begin{tabular}{|l|l|l|c|c|c|}
\hline Table 2: & Group 2 & $\begin{array}{l}\text { Time taken before green tea } \\
\text { intake in minutes }\end{array}$ & 9.67 & 2.66 & \multirow{2}{*}{0.047} \\
\cline { 2 - 5 } & $\begin{array}{l}\text { Time taken after green tea } \\
\text { intake in minutes }\end{array}$ & 6.83 & 2.79 & \\
\hline
\end{tabular}

\section{Comparison of groups}

\begin{tabular}{|l|l|c|c|c|c|}
\hline & & \multirow{2}{*}{$\begin{array}{c}\text { Mean } \\
\text { difference }\end{array}$} & \multicolumn{2}{|c|}{ 95\% CI } & \multirow{2}{*}{ P value } \\
\cline { 3 - 5 } $\begin{array}{l}\text { Between group 1 \& 2 } \\
(\mathrm{n}=12)\end{array}$ & $\begin{array}{l}\text { Time taken before } \\
\text { green tea in minutes }\end{array}$ & 0.333 & -5.93369 & 6.60035 & 0.908 \\
\cline { 2 - 4 } & $\begin{array}{l}\text { Time taken after green } \\
\text { tea in minutes }\end{array}$ & 0.666 & -3.76 & 2.42 & 0.641 \\
\hline $\begin{array}{l}\text { Between Group 1\& } \\
\text { Control (n=12) }\end{array}$ & $\begin{array}{l}\text { Time taken after green } \\
\text { tea in minutes }\end{array}$ & 0.425 & -2.07 & 2.92 & 0.713 \\
\hline $\begin{array}{l}\text { Between Group 2\& } \\
\text { Control (n=12) }\end{array}$ & $\begin{array}{l}\text { Time taken after green } \\
\text { tea in minutes }\end{array}$ & 0.242 & -3.33 & 2.84 & 0.865 \\
\hline $\begin{array}{l}\text { Between 2 groups \& } \\
\text { control (n=18) }\end{array}$ & $\begin{array}{l}\text { Time taken after green } \\
\text { tea in minutes }\end{array}$ & & & & 0.876 \\
\hline
\end{tabular}

\section{Discussion}

The present study demonstrated that administration of green tea catechins improves the spatial learning abilities of rats with an improved performance in radial maze tasks. The neuroprotective effect of green tea catechins may be due to their antioxidant property. Green tea catechins can protect against neuronal degenerative stress and also reduce the accumulation of 
lipid peroxides and reactive oxygen species. ${ }^{17}$ During ageing there is an imbalance between the oxidants and antioxidants. The lipid peroxides and reactive oxygen species accumulate and induce oxidative stress in cells and tissues. An increase in the production of lipid peroxide (LPO) exacerbates the neurodegenerative process by deteriorating cellular enzymes. Antioxidative enzymes are activated by green tea catechin intake and the antioxidative potency of plasma increases with continual ingestion of green tea. These antioxidative defense systems might also prevent oxidative damage in the brain. Long-term intake of green tea catechins may be important because cells are constantly exposed to oxidative stress. Also increase levels of oxidants causes a decline in the spatial learning abilities. Hence green tea catechins by their antioxidant property provide improved spatial learning memory.

In addition to these properties, recent findings have suggested that green tea may exert its neuroprotective effect through a variety of different mechanisms. Tea polyphenols inhibits acetylcholinesterase, which is a target for Alzheimer's disease medications. ${ }^{18}$ Green tea extracts plays a role in regulating the secretion of stress hormones such as corticosterone, which in turn is related to cognitive function. ${ }^{19}$ The L-theanine modulates neurotransmission in serotoninergic, dopaminergic ${ }^{20-22}$ and GABAergic ${ }^{23}$ neurons in brain. An enhancement of parieto-frontal connectivity by green tea consumption was also reported. ${ }^{24}$

The emerging data indicate that the antioxidant/ metal-chelating attributes of the catechins are unlikely to serve as the sole explanation for their neuroprotective and neurorescue effects. EGCG is brain permeable and can modulate cell survival and cell cycle genes and promotes neurogenesis. EGCG has a role in regulating the secretory processing of nonamyloidogenic APP through the protein kinase $\mathrm{C}$ pathway. ${ }^{14-16}$ Thus the green tea catechins provide neuroprotection against $A \beta$ amyloid.

\section{Conclusion}

The results of this study showed that green tea consumption may be effective in improving cognitive spatial learning abilities and hence can be used an effective tool in delaying cognitive impairment in elderly.

\section{References}

1. Fernandez PL, Pablos F, Martin MJ, Gonzales AG. Study of catechin and xanthine tea profiles as geographical tracers. Journal of Agricultural and Food Chemistry. 2002;50 (7):1833-9.

2. Graham HN. Green Tea Composition, Consumption, and Polyphenol Chemistry. Preventive Medicine. 1992; 21 334-350. DOI: 10.1016/0091-7435(92)90041-F.

3. Chu DC, Juneja LR. General chemical composition of green tea and its infusion. Chemistry and Applications of Green Tea. 1997; CRC Press, New York, 3- 22.
4. Sabu M Chacko, Priya T Thambi, Ramadasan Kuttan, and Ikuo Nishigaki: Beneficial effects of green tea: A literature review. Chinese Medicine. 2010;5:13. DOI: 10.1186/1749-8546-5-13.

5. Molinari M, Watt K D, Kruszyna T, Nelson R,Walsh M, Huang WY, Nashan B,Peltekian K. Acute liver failure induced by green tea extracts : case report and review of literature. Liver transplantation. 2006;12(12),1892-95.

6. Weinreb O, Mandel S, Amit T, Youdim M.B.H. Neurological mechanisms of green tea polyphenols in Alzheimer's and Parkinson's diseases. The Journal of Nutritional Biochemistry. 2004;15(9):506-16.

7. Dona M, Dell'Aica I, Calabrese F, Benelli R, Morini M, Albini A, Garbisa S. Neutrophil Restraint by Green Tea: Inhibition of Inflammation, Associated Angiogenesis, and Pulmonary Fibrosis. The Journal of Immunology. 2003; 170:4335-41.

8. Haqqi TM, Anthony DD, Gupta S, Ahmad N, Lee MS, Kumar GK, Mukhtar H. Prevention of Collagen-Induced Arthritis in Mice By a Polyphenolic Fraction from Green Tea. Proceedings of the National Academy of Sciences of the United States of America. 1999;96(8):4524-9.

9. Sudano Roccaro A, Blanco AR, Giuliano F, Rusciano D, Enea V. Epigallocatechin-gallate enhances the activity of tetracycline in staphylococci by inhibiting its efflux from bacterial cells. Antimicrobial Agents and Chemotherapy. 2004;48(6): 1968-73.

10. Sartippour MR, Shao ZM, Heber D, Beatty P, Zhang L, Liu C, Ellis L, Liu W, Go VL, Brooks MN. Green tea inhibits vascular endothelial growth factor (VEGF) induction in human breast cancer cells. The Journal of Nutrition. 2002;132(8):2307-11

11. Osada K, Takahashi M, Hoshina S, Nakamura M, Nakamura S, Sugano M. Tea catechins inhibit cholesterol oxidation accompanying oxidation of low density lipoprotein in vitro. Comparative Biochemistry Physiology Part C: Toxicology \& Pharmacology. 2001;128(2):153-64.

12. Weber JM, Ruzindana-Umunyana A, Imbeault L, Sircar S. Inhibition of adenovirus infection and adenain by green tea catechins. Antiviral Research. 2003 Apr;58(2):167-73.

13. Raederstorff DG, Schlachter MF, Elste V, Weber P. Effect of EGCG on lipid absorption and plasma lipid levels in rats. The Journal of Nutritional Biochemistry. 2003 Jun;14(6):326-32.

14. Weisburger JH. Tea and health: a historical perspective. Cancer Letters. 1997; 114(1-2): 315-317. DOI: 10.1016/S0304-3835(97)04691-0.

15. Kaur T, Pathak CM, Pandhi P, Khanduja KL. Effects of green tea extract on learning, memory, behavior, and acetylcholinesterase activity in young and old male rats. Brain and Cognition. 2008 Jun;67(1):25-30.

16. Flôres MF, Martins A, Schimidt HL, Santos FW, Izquierdo I, Mello-Carpes PB, Carpes FP. Effects of green tea and physical exercise on memory impairments associated with aging. Neurochemistry International. 2014 Dec; 78: 53-60. DOI: 10.1016/j.neuint.2014.08.008.

17. Levites Y, Weinreb, et al. Green tea polyphenol (-)epigallocatechin-3-gallate prevents N-methyl-4-phenyl1,2,3,6-tetrahyropyridine-induced dopaminergic neurodegeneration. Journal of Neurochemistry. 2001;78:1073-82.

18. Kim H.K., Kim M., Kim S., Kim M., Chung J.H. Effects of green tea polyphenol on cognitive and acetylcholinesterase activities. Bioscience Biotechnology Biochemistry. 2004;68:1977-9. 
19. Lee B., Sur B., Kwon S., Yeom M., Shim I., Lee H.,

Hahm D.H. Chronic administration of catechin decreases depression and anxiety-like behaviors in a rat model using chronic corticosterone injections. Biomolecules \& Therapeutics (Seoul). 2013;21:313-22.

20. Juneja L.R., Chu D.C., Okubo T., Nagato Y., Yokogoshi H. 1-Theanine-A unique amino acid of green tea and its relaxation effect in humans. Trends in Food Science \& Technology. 1999;10:199-204.

21. Yokogoshi H., Mochizuki M., Saitoh K. Theanineinduced reduction of brain serotonin concentration in rats. Bioscience Biotechnology Biochemistry. 1998;62:816-7.

22. Yokogoshi H., Kobayashi M., Mochizuki M., Terashima T. Effect of theanine, r-glutamylethylamide, on brain monoamines and striatal dopamine release in conscious rats. Neurochemical Research. 1998;23:667-73.

23. Yamada T, Terashima T, Kawano S, Furuno R, Okubo T, Juneja LR, Yokogoshi H: Theanine, gammaglutamylethylamide, a unique amino acid in tea leaves, modulates neurotransmitter concentrations in the brain striatum interstitium in conscious rats. Amino Acids. 2009 Jan;36(1):21-7.

24. Schmidt A., Hammann F., Wölnerhanssen B., MeyerGerspach A.C., Drewe J., Beglinger C., Borgwardt S. Green tea extract enhances parieto-frontal connectivity during working memory processing.

Psychopharmacology (Berl.). 2014;231:3879-88. 